Sociohistórica, nº 40, e040, 2do. Semestre de 2017. ISSN 1852-1606

Universidad Nacional de La Plata.

Facultad de Humanidades y Ciencias de la Educación.

Centro de Investigaciones Socio Históricas

\title{
Montaje de imágenes, historia y revolución
}

\author{
Reseña de Pittaluga Roberto. Soviets en Buenos Aires. La izquierda de la \\ Argentina ante la revolución en Rusia. Buenos Aires, Prometeo, 2015. 400 \\ págs.
}

\section{Matías Mamonde *}

* Facultad de Humanidades y Ciencias de la Educación. Universidad Nacional de La Plata, Argentina | matiasmamonde90@gmail.com

Soviets en Buenos Aires. La izquierda de la Argentina ante la revolución en Rusia es la adaptación al formato libro de la tesis doctoral desarrollada por Roberto Pittaluga. En principio, el escrito indaga en las diversas discusiones que se da la izquierda argentina frente a la revolución rusa en el momento mismo de su emergencia, lo que es en sí mismo un aporte valioso para la historia de las izquierdas. Sin embargo, esas discusiones son el escenario elegido por al autor para hacer visible toda una trama nocional, no necesariamente inteligible para los propios actores, que constituye al campo de la izquierda mismo, y que se ve trastocada por el acontecimiento revolucionario. Esta trama, inestable y múltiple, es el objeto de análisis, y hacia dónde se dirige el interés principal de Pittaluga. En cada intervención de los muy variados actores analizados; militantes de base, referentes políticos, teóricos de la izquierda, y en cada discusión que el acontecimiento actualiza o funda, se pone en acto todo el conjunto de nociones y saberes constitutivos de la cultura política de la izquierda argentina.

El libro se organiza en dos grandes secciones, la primera tiene como centro problemático a las distintas tradiciones de la izquierda argentina, y la manera en que estas se enfrentan con el acontecimiento revolucionario. Esta problemática, a su vez, viene imbricada con otras que se van desplegando en los apartados “Textos y actos”, “Qué y cómo leer”, “Qué mostrar” y, “Conflictos I”. Así, el autor muestra la gran variedad de textos y actos que se produjeron en la Argentina a propósito de la revolución. Abarcando diversas fuentes, desde las denuncias de la supuesta 
conspiración bolchevique que rodearon la represión durante la denominada "semana trágica”, hasta distintas conferencias, publicaciones, celebraciones, traducciones, relatos de viajes, y comités de apoyo, Pittaluga evidencia una verdadera

[G]uerra interpretativa [que] no comporta solamente una diferencia entre buena y mala información, entre verdad y mentira, entre fábula y realidad, sino que su dimensión más propiamente política consiste en determinar las percepciones colectivas de lo que se nombra como “revolución rusa”. (Pittaluga, 2016, p. 48)

Cada una de estas intervenciones, a través de dichos, omisiones, contextos, énfasis, compone imágenes en disputa sobre lo que la denominación "revolución rusa” determina. De esta manera, concluye el autor, construir la imagen de una "Rusia arrasada" (p.48), o de un "acto de vanguardia" (p. 50) para definir la experiencia soviética, implica una verdadera "política de lo visible” (p. 48), que actúa como un aspecto central en la interpretación y toma de posición frente al acontecimiento.

A su vez, esta disputa interpretativa se inscribe en un contexto muy particular que el autor reconstruye en el apartado "Conflictos I". En él se enumeran una serie de dimensiones constitutivas del escenario social y político de la época. El incremento de la actividad huelguística durante el quinquenio 1917-1921, el fortalecimiento de las organizaciones gremiales, tanto de la FORA del IX Congreso como del V Congreso, y su mayor disposición a la unidad, como también la constitución de grandes sindicatos industriales, son las principales dimensiones que atañen al mundo de las organizaciones obreras.

Además, como respuesta patronal a estos procesos, Pittaluga señala la conformación de la Asociación del Trabajo, la apelación a la represión estatal y paraestatal, junto a la movilización reaccionaria de los sectores medios y altos nucleados en la denominada Liga Patriótica, que en conjunto terminan por detener el ascenso de las luchas obreras.

Para completar este panorama, se señalan otros elementos importantes de la coyuntura; la emergencia de nuevas generaciones de militantes, tanto socialistas como anarquistas, las discusiones en torno a la ampliación democrática luego de la nueva ley electoral, y las problemáticas planteadas sobre las perspectivas futuras del modelo de crecimiento agroexportador. En definitiva, concluye el autor

Fue en esta trama social y política, ciertamente conmovida, que se inscribieron también las noticias de los sucesos revolucionarios en Rusia. En esta situación se desajustaron las viejas percepciones de importantes sectores de la sociedad, y en particular entre los sectores obreros y populares se produjeron alteraciones en las representaciones que sobre el cambio social, sobre sus posibilidades efectivas, se habían construido, especialmente entre sus formaciones de vanguardia. La "revolución rusa”, como lugar y a la vez desafío, intervenía en las tensiones constitutivas del universo político y conceptual de la izquierda. (p. 62)

En este marco, cada una de las secciones que componen el apartado “Conflictos II” se ocupa de la problemática en torno a las lecturas de la revolución rusa en el mundo de las distintas tradiciones de la izquierda. Así, el autor señala la manera en que cada una de estas lecturas, produciendo una 
especie de torsión, se dirigen hacia la revolución y, al mismo tiempo, hacia la propia izquierda local. "Representaciones alteradas" atiende al espacio socialista en el cual la problemática de la representación política, la democracia parlamentaria, y la adhesión a las Internacionales, son algunas de las temáticas más discutidas a propósito de la revolución.

El apartado “Desconciertos identitarios” se ocupa del anarquismo, y además de aportar una matizada delimitación entre las facciones que valoran positiva o negativamente la experiencia soviética, construyendo etapas de mayor adhesión o distanciamiento, el autor señala las discusiones en torno a las implicancias de la dictadura del proletariado, la escisión entre medios y fines reconocida en la lógica burocratizada del Estado soviético, y “el problema del nombre”, (p. 82) relativo a la disputa por el significante comunismo entre los anarquistas y los miembros del flamante Partido Comunista.

“Qué lugar hacer(se)” refiere a la emergente tendencia comunista. En este caso, la problemática de la demarcación de un lugar propio frente al resto de las facciones de la izquierda, especialmente del socialismo, resulta central. Por un lado, Pittaluga reconoce distintas estrategias discursivas desarrolladas por parte de los comunistas, entre ellas, la narrativa sobre el origen del partido. Este aspecto le permite al autor discutir con cierta historiografía que tiende a incorporar en sus análisis sobre el surgimiento del PSI/PC, los supuestos de dicha explicación nativa, de manera poco crítica. Por otro lado, el autor reconstruye las interpretaciones de la revolución rusa generada en el interior de dicho espacio, mostrando cómo estas interpretaciones condensan buena parte de los elementos de crítica del comunismo frente a la tendencia socialista. Así, los clivajes base-dirección, gremialismoelectoralismo, democracia-representación, reforma-revolución, resultaron fundamentales en la constitución misma de la tendencia comunista.

Por último, “Cómo preservar el lugar” atiende a las organizaciones de la tradición sindicalista revolucionaria. En este caso, la experiencia soviética enfrenta a los sindicalistas con un problema fundamental, preservar los lugares que habían conquistado en el marco de una estrategia de negociación con la dirigencia gubernamental. El escenario elegido por el autor para observar esta problemática, será la discusión en torno a las opciones de adherir a la nueva Internacional Sindical Roja, promovida por los bolcheviques, o bien mantenerse alineados en la tradicional Federación Sindical Internacional, conformada durante la II Internacional.

La segunda sección del libro avanza en un sentido diferente, el análisis ya no se detiene en cada una de las particiones de la izquierda, ni en el pensamiento político de un grupo en particular, sino que se orienta hacia temáticas de gran abstracción, “Tiempo", "Sujetos”, "Régimen”, "Sociedad”, "Cultura” y "Espacio". Este recurso resulta especialmente productivo en varios sentidos. Por un lado el autor genera nuevos agrupamientos, clivajes, y problemáticas que trascienden la separación clásica entre socialistas, anarquistas, comunistas, y sindicalistas, reconociendo consensos y tensiones poco señaladas en otros abordajes, y ampliando las posibilidades de análisis hacia dimensiones muy poco exploradas, y que sin embargo, tal como evidencia el escrito, poseen una gran densidad que merece ser atendida. De esta manera, la escisión entre nociones lineales y no lineales del tiempo histórico, las interpretaciones en torno a la idea de agencia que impulsa a las revoluciones, distintas variaciones sobre la vinculación entre revolución y ley, o la toma de posición en torno a la posibilidad de replicar la revolución en espacios alternos al que le dio origen, son 
algunas de las múltiples problemáticas que se despliegan a lo largo de toda la sección.

Para finalizar quisiera señalar un elemento que está presente en el libro de Pittaluga, aunque no haya más que sugerencias al respecto. Me refiero a la impronta benjaminiana que evidencia el escrito. Sin la intención de simplificar la compleja relación entre el procedimiento del Montaje de imágenes, y su conexión con una concepción del tiempo no lineal, fundamental en la obra de Walter Benjamin, y señalando que su presencia en este escrito está adherida a objetivos que son propios del autor, y convive con la referencia de muchos otros autores, diremos, al menos, que el formato de Soviets en Buenos Aires tiene una clara filiación con el procedimiento del Montaje de Imágenes. Confiando en la fuerza comunicativa-experiencial de las imágenes como forma de acceso a los fenómenos histórico-sociales, y privilegiando un estilo de exposición intermitente y no lineal, el escrito expresa un productivo uso de la filosofía benjaminiana. Este recurso posibilita, al mismo tiempo, un aporte cognoscitivo, recuperando la significación del momento analizado, y de esta manera un intento por devolverle a ese pasado, frustrado en buena medida, su actualidad. 